\title{
친환경 압전체
}

\section{친환경 압전체 개발 현황 및 기본 물성 연구 흐름}

DOI: $10.3938 /$ PhiT. 22.001

\section{송태권·문승언}

\section{Development of and Basic Property Research Trends in Environment-friendly Piezoelectric Materials}

\section{Tae Kwon SONG and Seung Eon MOON}

The development of environment-friendly piezoelectric materials to replace $\mathrm{Pb}(\mathrm{Zr}, \mathrm{Ti}) \mathrm{O}_{3}$ (PZT), which is used for actuators, sensors, and other various applications, is urgent. The phase transition and the morphotropic phase boundary behaviors in niobates are much different from those in titanates where PZT belongs. The basic understandings of piezoelectric and ferroelectric phase transitions are very important to get lead-free piezoelectrics with high piezoelectric coefficients and high ferroelectric phase transition temperatures.

\section{서 론}

압전 액추에이터 모터 등 압전체 응용 연구를 주도해온 미국 펜실베이니아 주립대 우치노 교수는 최근의 과학-기술-사회의 관계는 전통적인 관계와 완전히 다른 경향을 보인다고 주장한 다. 전통적으로는 이론과 실험을 통하여 새로운 과학이 정립되 면 이를 바탕으로 관련 기술이 발달하고 관련 산업이 발달하여 사회에 영향을 미치게 되면 바른 방향으로 그 영향력을 이끌기 위해 관련 법규와 같은 규제들이 만들어진다는 것이다. 과학과

\footnotetext{
저자약력

송태권 교수는 서울대학교 이학 박사(1995)로서 미국 메릴랜드 대학교 연 구원 등을 거쳐 2000년부터 창원대학교 교수로 재직 중이다. 비납계 압전 세라믹 및 박막에 대한 연구를 진행 중이다. (tksong@changwon.ac.kr)

문승언 박사는 서울대학교 이학 박사(2000)로서 2000년부터 한국전자통 신연구원에서 재직 중이다. 현재 압전체를 이용한 센서/엑추에이터/에너지 수확 소자와 멤스 구조물을 이용한 가스 센서 관련된 연구를 진행 중이다. (semoon@etri.re.kr)
}

기술이 발전하면서 과학이 기술로 응용되고 산업 및 사회에 적 용되는 기간이 짧아지기는 하였지만 그 순서가 바뀌지는 않았 는데 최근에는 그 순서가 완전히 뒤바뀌었다는 것이다. 지구 온 난화 등의 문제로 환경 문제가 인류의 중요한 문제로 떠오르면 서 환경 규제가 먼저 일정한 기한을 두고 제시되면, 그와 관련 된 기술의 요구로 연구와 개발이 진행되고 이에 기본적인 과학 에 대한 보다 깊은 이해를 바탕으로 한 기술의 개발이 이루어 진다는 것이다. ${ }^{[1]}$

최근 친환경 조명으로 응용되고 있는 $\mathrm{LED}($ 혹은 $\mathrm{LD})$ 는 레이 저와 반도체와 같은 기본적인 과학 연구에서 출발하고 있다. 전 구를 아무리 공학적으로 개발을 하더라도 레이저와 같은 강한 빛을 내는 방법을 찾지 못하였을 것이라는 이야기가 있다. 이 이야기는 지나치게 실용적인 응용을 목적으로 한 단기적인 연 구만으로는 그 실용적인 목적을 위한 돌파구를 마련하기 어려 울 수 있다는 주장의 구체적인 시례를 제공한다. 그렇지만 이런 성공적인 사례가 일반적인 경우라고 보기는 어렵다.

유전체(dielectrics)의 여러 현상 중에서 강유전성(ferroelectricity)은 고체 구조 상전이와 관련하여 많은 연구가 진행되었 다. 강유전성이 발견되기 전에 재료 안의 분극(polarization) 크 기가 온도에 따라 변하는 초전 현상(pyroelectricity)이 1856년 에, 기계적인 변위와 전기적인 분극값이 서로 결합되는 특성인 압전 현상(piezoelectricity)은 1880년에 유명한 큐리(Curie) 형 제에 의하여 발견되었다. 강유전 현상은 압전 및 초전 현상을 보이는 재료 중에서 분극이 외부 전기장에 의하여 스위칭이 일 어나는 물질로 1920년 로셀염이라는 독특한 물질에서 처음 발 견되었다. 일반적으로 강유전 현상이 강자성 현상fferromagnetism)과 비슷한 현상으로 언급이 되는데 강자성 현상이 고대 에서부터 알려진 현상인데 비하여 강유전 현상은 발견된 지 100 년이 채 되지 않은, 초전도 현상보다도 늦게 발견된 새로운

\section{REFERENCES}

[1] K. Uchino, The 8th Asian Meeting on Electrocramics, Penang, Malaysia 2012 
물리 현상이다. ${ }^{[2]}$

1935년 $\mathrm{KH}_{2} \mathrm{PO}_{4}$ 라는 물질과 이의 동소체에서 강유전성이 발 견되어 강유전 현상에 대한 많은 연구가 이루어졌으나, 1945년 소련과 미국, 일본에서 거의 동시에 상온에서 유전상수가 아주 큰 티탄산 바륨(BT, $\mathrm{BaTiO}_{3}$ )이 발견됨으로써 축전기(capacitor) 재료로 널리 활용되었다. BT의 발견은 응응과 기초연구의 측면 에서 모두 큰 관심을 끌게 되는데, 응용의 측면에서의 기존의 강유전체가 공기 중의 습기에 약한데 비하여 $\mathrm{BT}$ 는 산화물 세 라믹으로 만들어져 주위 환경에 강하다는 장점이 있다. 기초 연 구의 측면에서도 기존의 강유전체에 비하여 간단한 구조를 가 지며 $120{ }^{\circ} \mathrm{C}$ 주위의 강유전 상전이뿐만 아니라 상온 아래에서의 두 번의 상전이 현상을 더 가지기 때문에 고체의 구조 상전이 연구의 대표적인 물질로 관심을 끌었다. 그 이후 우수한 압전특성 및 주파 수 안정성이 뛰어난 $\mathrm{Pb}(\mathrm{Zr}, \mathrm{Ti}) \mathrm{O}_{3}$ (PZT)계 세라믹스가 발견되어 응용이 확대되었다. 더욱이 $\mathrm{Pb}\left(\mathrm{Fe}_{1 / 2} \mathrm{Ta}_{1 / 2}\right) \mathrm{O}_{3}, \mathrm{~Pb}\left(\mathrm{Mg}_{1 / 3} \mathrm{Nb}_{2 / 3}\right) \mathrm{O}_{3}$ 등 복합 페로브스카이트(perovskite)계 등의 소재가 개발됨으로 써 사용 온도의 제한이나 특성의 변화를 쉽게 제어할 수 있는 장점으로 압전세라믹스의 응용에 대한 개발이 본격적으로 시작 하게 되었다.

이러한 압전체/강유전체에 대한 연구는 해방 이후 단결정 성 장 등의 연구를 중심으로 우리나라에서도 꾸준히 진행되었고 1991년 부산대 유전체물성연구소를 중심으로 발전을 이루어 1997년 이른바 강유전체 연구의 올림픽이라고 불리는 강유전 체 국제학술대회(IMF, International Meeting on Ferroelectricity)를 서울에서 개최하기에 이르렀다. ${ }^{[3]}$ 이를 바탕으로 우리나 라의 연구 수준은 세계적인 수준에 이르렀으나 전통적으로 튼 튼한 연구 기반을 가지고 있는 일본과 많은 인력의 힘을 바탕 으로 한 중국의 압력에 어려움을 겪고 있는 것도 현실이다.

\section{압전체의 응용}

$\mathrm{BT}$ 의 결정구조는 이른바 $\mathrm{ABO}_{3}$ 로 표현되는 페로브스카이트 구조를 갖는다. 페로브스카이트는 자연 광물인 $\mathrm{CaTiO}_{3}(\mathrm{CT})$ 에서 나왔는데 실제로 $\mathrm{CT}$ 는 강유전성을 보이지 않으며 강유전 혹은 압전 특성을 보이는 페로브스카이트 물질들은 인공적으로 만들 어진 화합물들이다. 페로브스카이트는 A와 B 자리에 어떤 원소 가 치환되는가에 따라 다양한 조합의 화합물이 가능하며 다양 한 화합물의 다양한 물성을 바탕으로 하여 강유전체 혹은 압전 체를 이용한 축전기(MLCC, Multi-Layer Ceramic Capacitor), 압전소자, 마이크로웨이브 통신 응용, 초전 현상을 이용한 적외 선 감지기, 강유전 기억소자 등의 다양한 응용에 활용되는 물질 은 대부분 이 페로브스카이트 결정 구조를 가지고 있다.

압전 재료로 가장 널리 알려진 PZT는 페로브스카이트 A 자

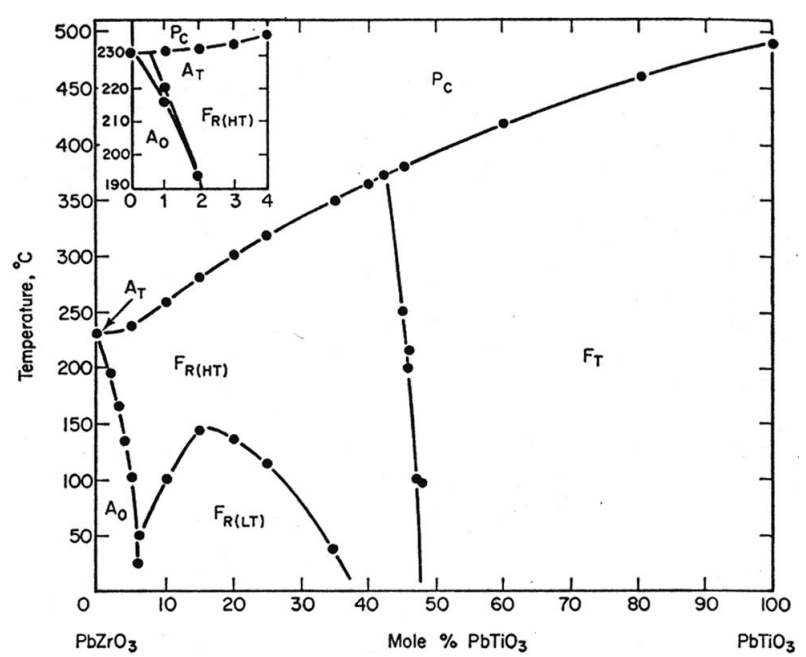

Fig. 1. Phase diagram of $\mathrm{Pb}(\mathrm{Zr}, \mathrm{Ti}) \mathrm{O}_{3}$ system. Morphotropic phase boundary locates around 48 mole\% $\mathrm{PbTiO}_{3}{ }^{[4]}$

리에 납 $(\mathrm{Pb})$ 이 B 자리에는 Ti와 $\mathrm{Zr}$ 이 혼합되어 있는 티탄산 납 $\left(\mathrm{PT}, \mathrm{PbTiO}_{3}\right)$ 과 지르코늄산 납 $\left(\mathrm{PZ}, \mathrm{PbZrO}_{3}\right)$ 의 고용체 $($ solid solution)이다. PZT는 Ti과 Zrof 비에 따라, 그리고 $\mathrm{La}$ 이나 $\mathrm{Nb}$ 과 같은 첨가물에 따라 다양한 물성을 변화를 보여주기 때문에 PZT도 다양한 응용 분야에 활용된다. 지난 20년 정도 큰 관심 을 끌고 연구되어진 강유전 기억 소자의 경우 Ti이 많은 조성 영역의 재료들이 사용되며, 적외선 감지기는 $(\mathrm{Pb}, \mathrm{La}) \mathrm{TiO}_{3}$ 가 활 용된다. 특히 압전 재료로 활용되는 조성은 그림 1 의 상태도에 나타내어진 것과 같이 Ti과 Zr이 거의 반반씩 들어있는 이른바 상경계 영역(MPB, Morphotropic Phase Boundary)의 조성으 로서 결정구조가 사방정계(orthorhombic)와 정방정계(tetragonal) 를 함께 가지게 되어 외부 전기장에 의하여 분극이 쉽게 방향 을 바꿀 수 있게 되어 좋은 압전 특성을 보이는 것으로 알려져 있다. ${ }^{[4]}$ 이런 현상은 강유전 상전이 온도 주위에서 강유전체가 아주 큰 유전 상수를 보이는 것과 비슷하게 생각할 수 있는데, 상경계 영역은 온도 변화에 의해서가 아니라 조성의 변화에 따 라 특성이 나타난다는 점이 다른 점이다. 일반적으로 이야기되 는 PZT는 이런 압전 응용을 위한 MPB 조성을 바탕으로 하여 특성의 온도 의존성 등을 고려하여 몇 가지 첨가 물질을 포함 하는 것이 일반적이다.

현재 압전체는 자성체에 비해 큰 에너지 변환 효율 특성으로 압전 변압기 외에도 최근에 에너지변환 소자에도 적용 연구 중 이고, 작은 부피로 큰 힘을 발생시키고 높은 정밀도 특성으로

\section{REFERENCES}

[2] S-I. Kwun et al., Introduction to Ferroelectrics (Korean) (Seoul National University Press, 2000).

[3] Tae W. Noh, Phys. High Technol. 7(6), 46 (1998).

[4] B. Jaffe et al., Piezoelectric Ceramics (Academic Press, 1971). 
전자현미경, 광학장치, 정밀 절삭 장치, 자동차 등 소형화가 필 요한 다양한 엑추에이터에 적용 중이다. 또한 높은 주파수에서 작동 가능하여 음향 공진기나 필터에 사용 중이고 초음파 진동 자로 사용하며 마찰이나 마모가 없어 유량 측정기, 초음파 진단 기 등으로 사용 중이다. 자기장의 영향을 받지 않으므로 핵자기 공명장치 내 엑추에이터로도 사용 중이고 과다전류에도 화재의 위험이 없어 가스렌지나 가스라이터용 착화소자 등의 분야에서 전통적으로 널리 응용되고 있지만, 최근 들어 고정밀 위치/변위 /유량 제어용으로 압전 엑추에이터가 소형화 및 기능화하여 그 수요가 점차 늘고 있는 실정이다. 이에 반해 단점은 대변형을 발생시키기 힘들고, 깨지기 쉬우며, 고전압을 가해야 하며, 큐 리 온도 이상이 되면 압전성을 잃기 시작하며, 히스테리시스가 있지만 현재 이러한 단점을 적층형이나 복합 소재 설계나 소자 구조 또는 되먹임 제어 등을 통해 해결하려는 연구들도 많이 진행되고 있다.

그런데 현재 유럽에서 시행 중인 $\operatorname{RoHS}$ (유해 물질 제한, Restriction of Hazardous Substances) 규정은 납, 카드뮴, 6 가 크롬 등과 같은 유해한 물질의 사용을 제한하고 있다. 납의 경우 회로 기판의 납땜 재료로 널리 사용된 납은 이미 대체 물 질의 개발로 사용이 금지되었으나, 전자 재료에 활용되는 PZT 의 경우 아직 대체 물질이 완전히 개발되지 않아 아직은 완전 금지가 유보된 상황이다. ${ }^{[5]}$ PZT의 경우 납이 산화물의 형태이 기 때문에 유해성이 덜하다고 하나 제조나 폐기 시의 환경오염 의 문제는 피할 수 없으며, 특히 심박조절기와 같이 인체에 적 용되는 의료 기기 응용에는 피해야 할 물질이다. 그러니까 납을 포함하지 않는 압전 재료의 개발은 레이저가 개발되기도 전에 전구를 대체할 $\mathrm{LED}$ 를 만들어야 하는 상황과 유사하다고 볼 수 있을 것 같다.

\section{압전체 시장}

압전재료의 응용분야로는 표 1 에 나타낸 것과 같이 기계에너 지를 전기에너지로 변환시키는 기능을 활용한 센서분야, 전기에 너지를 기계에너지로 변환시키는 기능을 활용한 기계적 힘 발 생원분야, 그리고 전기에너지를 기계에너지로 이를 다시 전기에 너지로 변환되는 복합적 기능을 활용한 전기회로 부품분야 등 으로 나눌 수 있는데 대표적으로 역학량 측정센서 혹은 음향센 서, 가스렌지 착화소자, 각종 세정기 및 가공기용 진동소자, 부 저 등의 음향 발생소자와 각종 전자기기의 음향필터, 변압기, 고정밀 엑추에이터 등으로 널리 응용되고 있다.

압전재료의 응용분야는 공진기와 필터와 같은 무선 통신 소 자, 센서, 잉크젯 펌프나 자동차용 밸브 그리고 고정밀 위치 제 어용 액추에이터, 스피커, 수중 소나나 초음파 진단용 초음파응
Table 1. Applications of piezoelectric ceramics.

\begin{tabular}{|c|c|c|}
\hline Transformation & Function & Applications \\
\hline \multirow{3}{*}{$\begin{array}{l}\text { Converse } \\
\text { Piezoelectric } \\
\text { Effect }\end{array}$} & $\begin{array}{l}\text { Ultrasound } \\
\text { generation }\end{array}$ & $\begin{array}{l}\text { Ultrasonic cleaner, Plastic welding } \\
\text { machine, Ultrasonic machine }\end{array}$ \\
\hline & $\begin{array}{l}\text { Sound } \\
\text { generation }\end{array}$ & Speaker, Buzzer \\
\hline & Actuator & $\begin{array}{l}\text { Ultrasonic motor, Inkjet printer, } \\
\text { Piezoelectric valve, Piezoelectric } \\
\text { pump }\end{array}$ \\
\hline \multirow{3}{*}{$\begin{array}{l}\text { Direct } \\
\text { Piezoelectric } \\
\text { Effect }\end{array}$} & $\begin{array}{l}\text { High-Voltage } \\
\text { generation }\end{array}$ & Gas igniter, Gas lighter \\
\hline & $\begin{array}{l}\text { (Ultra) sound } \\
\text { receiving }\end{array}$ & Microphone, Hydrophone \\
\hline & Sensor & $\begin{array}{l}\text { Accelerometer, Vibrometer, } \\
\text { Flowmeter, Piezoelectric } \\
\text { gyroscope, Manometer }\end{array}$ \\
\hline \multirow{3}{*}{$\begin{array}{l}\text { Direct+Converse } \\
\text { Piezoelectric } \\
\text { Effect }\end{array}$} & $\begin{array}{l}\text { Electric signal } \\
\text { processing }\end{array}$ & SAW filter, Resonator \\
\hline & $\begin{array}{l}\text { Measuring } \\
\text { distance }\end{array}$ & $\begin{array}{l}\text { Underwater Sonar, Echo sounder, } \\
\text { Medical ultrasound probe }\end{array}$ \\
\hline & \begin{tabular}{|l|} 
Voltage \\
transformation
\end{tabular} & Piezoelectric transformer \\
\hline
\end{tabular}

용소자, 부저나 착화소자 등 매우 다양하며, 그중 전체시장에서 주류를 차지하고 있던 무선 통신 소자에서 고정밀 액추에이터 나 초음파 응용 소자 또는 정보통신 소자로 비중이 옮겨지고 있는데 압전세라믹스의 세계 시장은 2005년 약 30억 불에 달 했으며, ${ }^{[6]} 2010$ 년 기준 약 148 억 달러에 달한다. ${ }^{[7]}$

그 중 대표적인 응용 소자인 압전 액추에이터 및 모터 등의 시장은 2009년 66억 달러를 기록했으며, 연평균 $13.2 \%$ 의 성 장률로 성장해 2014년 123억 달러에 달할 것이라고 전망된다. 그림 2는 다양한 압전 액추에이터 응용 소자를 보여주고 있다. 초정밀 기기용 압전 액추에이터와 모터의 세계 시장은 2009년 약 32억 불이고 연평균 증가율 $13.4 \%$ 로 2014년 약 60억 불 에 달할 것으로 예측되는데 이중 폰 카메라, 디지털 카메라, 현 미경 렌즈, 거울과 광학용 액추에이터의 세계 시장은 2009년 약 28억 불이고 연평균 증가율 $13.1 \%$ 로 2014년 약 52억 불 에 달할 것으로 예측된다. ${ }^{[8]}$

현재 압전재료로 응용되는 재료는 페로브스카이트 산화물 이 외에도 다양한 재료들이 응용되고 있는데 단결정, 다결정 세라 믹스, 고분자재료, 박막재료, 다결정재료와 고분자 재료를 복합

\section{REFERENCES}

[5] COMMISSION DECISION of 8 September 2011 (2011/534/ EU) Official Journal of the European Union.

[6] Fuji Chimera Research Institute, Potential Materials for Electronics Parts, Frontier Ceramics.

[7] Acmite Market Intelligence, 2011 


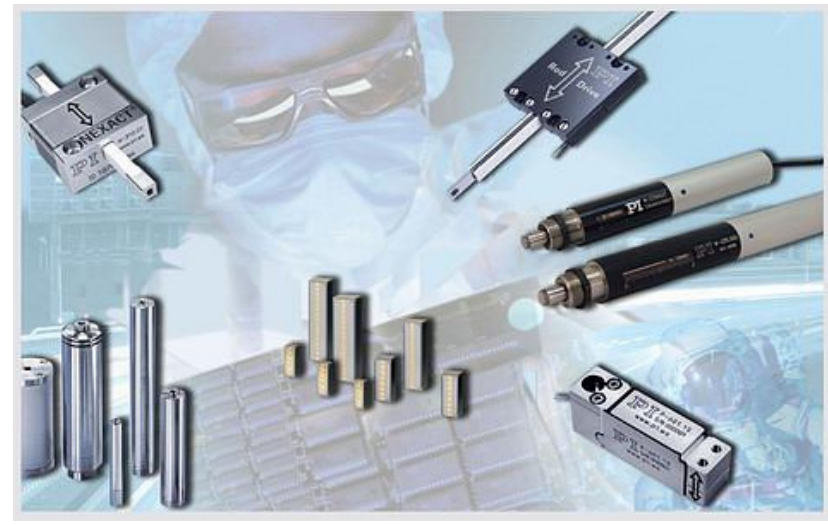

Fig. 2. Various piezoelectric actuators [www.pikorea.co.kr].

화한 복합재료로 나눌 수 있다. 단결정 재료로 널리 사용되는 수정은 공진주파수의 대역폭이 좁고 온도계수가 매우 작으므로 신호주파수를 발생하는 오실레이터 소자로 사용되며, 가격이 비 싸고 전기기계결합계수가 작은 단점이 있어 응용분야가 제한된 다. $\mathrm{LiNbO}_{3}$ 와 $\mathrm{LiTaO}_{3}$ 단결정과 $\mathrm{ZnO}$ 박막재료 등은 탄성표면 파(SAW: Surface Acoustic Wave) 필터로 응용되고 있으며 또 한 AlN, $\mathrm{ZnO}$ 등 박막재료는 새롭게 연구되고 있는 $\mathrm{GHz}$ 대역 FBAR(Film Bulk Acoustic wave Resonator) Bandpass Filter 재료로 응용되고 있다. 다결정 재료인 PZT계 세라믹스는 가공성이나 제반 압전특성이 우수하고 가격이 저렴하여 초음파 진동자, 필터, 레조네이터, 착화소자, 센서 및 엑추에이터 등에 가장 널리 응용되고 있다. 또한 고분자재료와 PZT계의 복합재 료는 재료의 특성상 시트형태로 가공이 쉽기 때문에 각종 키보 드나 수중 음향부품, 의료용 탐촉자 등에 주로 응용되고 있다.

이러한 압전체 응용의 새로운 연구 분야 중 하나가 압전 효 과를 이용하여 심장 박동 등 인체의 모든 운동을 전기 에너지 로 바꿀 수도 있다. 하지만 지금까지는 이런 생체 운동으로 전 기를 만드는데 한계가 있다. 생체 운동은 불규칙적이며 그 운동 에서 나오는 미세한 에너지를 거둬들이기도 쉽지 않기 때문인 데 최근 조지아공대 연구팀은 이런 문제를 해결하기 위하여 산 화아연 나노 선을 이용한 나노 발전기를 개발하였다. 이들은 집 게손가락에 나노 발전기를 붙여 키보드나 패드를 누르는 운동 을 전기로 변환하고 나노발전기를 장착한 옷을 햄스터에게 입 혀 이들이 쳇바퀴를 돌 때 전기를 생산하는 데 성공하였고 KIST와 성균관대에서는 이러한 나노선을 이용한 패치를 사람 피부에 부착하여 에너지를 수확하는 소자를 선보였다. 비록 나 노와트급의 아주 적은 양에 불과하지만 병원균이나 암세포의 단백질을 감지하는 나노 센서 등의 미세 기계 장치의 매우 유 용한 전력원이 될 것으로 기대된다.

이러한 압전체를 이용한 에너지 수확 기술은 다양한 환경에 서 버려지는 에너지를 전기로 바꿀 수 있는데 네덜란드와 영국

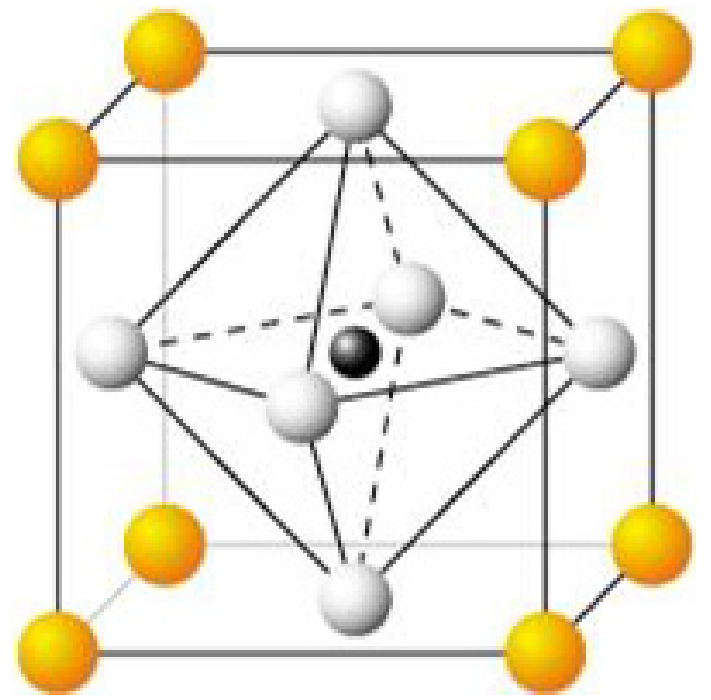

Fig. 3. Crystal structure of perovskite $\mathrm{ABO}_{3} ; \mathrm{A}($ Yellow), $\mathrm{B}$ (Black), O(White)

의 나이트클럽 바닥에 압전 소자가 설치되어 사람들이 춤을 추 며 바닥을 누르면 압력을 전기로 바꿔 조명에 쓰이고 있고 행 군하는 군인의 전투화나 도로에 압전 소자를 설치하여 발이 또 는 자동차가 노면에 전달하는 압력을 전기로 전환하여 통신용 또는 조명이나 교각의 안전도를 감시하는 센서 노드의 전원으 로 쓰이는 연구도 진행 중이다. 휴대폰의 입/출력 인터페이스 중의 하나로 유연 투명 압전 소재를 이용한 3D 촉각센서나 무 전원 키보드, 스피커와 촉감 디스프레이 용으로 압전 센서/액추 에이터가 활발히 연구 중이고, 에너지 변환 소재는 신성장동력 기반 세라믹소재형 산업육성 품목 중의 하나로 선정된 바 있다.

\section{친환경 압전체 개발 방향}

그럼 왜 아직도 압전 재료에 사용되는 납을 대체하지 못하는 가? 그 이유는 그림 3 에 나타낸 페로브스카이트 $\left(\mathrm{ABO}_{3}\right)$ 강유전 체의 상전이 현상과 상경계 영역을 활용한 압전 특성의 개선 방법과 관련이 있다. 이런 접근 방법은 현재 많은 연구가 진행 되고 있는 비납계 압전 재료의 연구 개발 방법과 연결되어 있 다. PZT와 같은 티타늄 산화물 혹은 지르코늄 산화물에서 페 로브스카이트 $\mathrm{A}$ 자리는 2 가의 원소인 $\mathrm{Ca}$ 과 $\mathrm{Sr}, \mathrm{Ba}, \mathrm{Pb}$ 가 가 능하다. 그런데 $\mathrm{Ca}$ 과 $\mathrm{Sr}$ 화합물의 경우 아주 낮은 온도에까지 강유전성을 보여주지 않으며 $\mathrm{Ba}$ 화합물(BT)은 상전이 온도가

\section{REFERENCES}

[8] PIEZOELECTRIC ACTUATORS AND MOTORS-TYPES, APPLICATIONS, NEW DEVELOPMENTS, INDUSTRY STRUCTURE AND GLOBAL MARKETS, APPLICATIONS, Innovative Research and Products, INC 2010. 
$120{ }^{\circ} \mathrm{C}, \mathrm{Pb}$ 화합물 $(\mathrm{PT})$ 은 상전이 온도가 $490{ }^{\circ} \mathrm{C}$ 정도를 가져 $\mathrm{A}$ 자리의 원소가 크거나 무거울수록 높은 상전이 온도를 갖는 다. 이러한 특성은 $\mathrm{A}$ 자리에 $\mathrm{Sr}$ 과 $\mathrm{Ba}, \mathrm{Pb}$ 를 혼합한 고용체의 경우도 일관된 경향을 보이는 것으로 알려져 있다. $\mathrm{B}$ 자리의 경우는 $\mathrm{A}$ 자리의 경우와 반대로 $\mathrm{Ti}$ 이 더 크고 무거운 $\mathrm{Zr}$ 으로 치환될 경우 상전이 온도가 더 낮아지는 것을 PZT의 경우 대 표적인 예로 볼 수 있다.

이렇게 높은 상전이 온도를 가지는 PT에 PZ를 혼합함으로써 상경계 영역을 유도하여 우수한 압전 특성을 유도함과 더불어 $300{ }^{\circ} \mathrm{C}$ 정도의 충분히 높은 온도의 상전이 온도를 가질 수 있 는 것이다. 이러한 충분히 높은 강유전 상전이 온도가 요구되는 것은 압전 소자의 동작 중에 발열이 일어나기 때문이며 특성의 안정성을 위해서도 적어도 $200{ }^{\circ} \mathrm{C}$ 이상의 상전이 온도가 요구 된다. 현재 PZT를 대체하기 위한 비납계 압전재료의 개발은 페 로브스카이트 재료의 개선을 중심으로 연구되고 있다. 엔진 연 료분사기 등에 사용되기 위해서는 큰 압전 계수 값을 가져야 하는데 다양한 강유전체 중 다른 결정 구조를 갖는 강유전체는 큰 압전 계수를 보여주지 못하고 있다. 그러나 큰 압전 계수를 필요로 하지 않는 공진기 등의 압전체 응용의 경우에는 비스무 스 층구조형 강유전체를 이용하여 납을 포함하지 않는 재료를 개발하여 이미 상용화되었다.

그러므로 비납계 압전체의 연구는 변위 응용을 위한 페로브 스카이트 결정구조를 바탕으로 한 큰 압전계수의 개발이라는 목표를 가지게 되고 이를 위하여 크게 세 가지 종류의 후보 물 질들을 중심으로 연구되고 있다. 첫 후보 물질군은 가장 잘 알 려진 강유전체인 티탄산 바륨(BT)을 바탕으로 하는 것이다. BT 는 그 자체로도 좋은 압전 특성을 보이기 때문에 비납계 압전 재료의 훌륭한 후보가 될 수 있으나 강유전 상전이 온도가 $120{ }^{\circ} \mathrm{C}$ 정도로 낮아서 실제 응용에는 큰 한계를 가지고 있다. 만약 BT의 상전이 온도를 충분히 높일 수 있는 첨가물을 발견 하면 응용 가능성이 높아진다. 그러나 지금까지 알려진 바로는 $\mathrm{BT}$ 에 첨가하여 상전이 온도를 충분히 높일 수 있는 물질은 유 감스럽게도 우리가 피하려고 하는 A-위치에 납을 치환하는 경 우가 유일하다.

두 번째 후보는 같은 티타늄 산화물로서 A-자리에 2 가의 원 자가를 만들어 주면서 무거운 원소가 포함되는 경우로서 비스 무스 $\left(\mathrm{Bi}^{3+}\right)$ 와 나트륨 $\left(\mathrm{Na}^{1+}\right)$ 이나 칼륨 $\left(\mathrm{K}^{1+}\right)$ 이 각 반씩 들어가는 화 합물로서 $\left(\mathrm{Bi}_{0.5} \mathrm{Na}_{0.5}\right) \mathrm{TiO}_{3}(\mathrm{BNT})$ 와 $\left(\mathrm{Bi}_{0.5} \mathrm{~K}_{0.5}\right) \mathrm{TiO}_{3}$ (BKT)를 바탕 으로 하는 물질들이다. 이들 물질들을 적당히 혼합하거나 $\mathrm{BT}$ 를 치환하는 방법으로 PZT에서와 같은 상경계 영역을 형성함으로 써 좋은 압전특성을 갖는 조성을 만들 수 있다. 그러나 이런 물질들은 BT와는 다른 상전이 현상을 보여주는데, $300{ }^{\circ} \mathrm{C}$ 정 도에서의 상전이 이후에 $100{ }^{\circ} \mathrm{C}$ 정도에서의 상전이를 하고 상

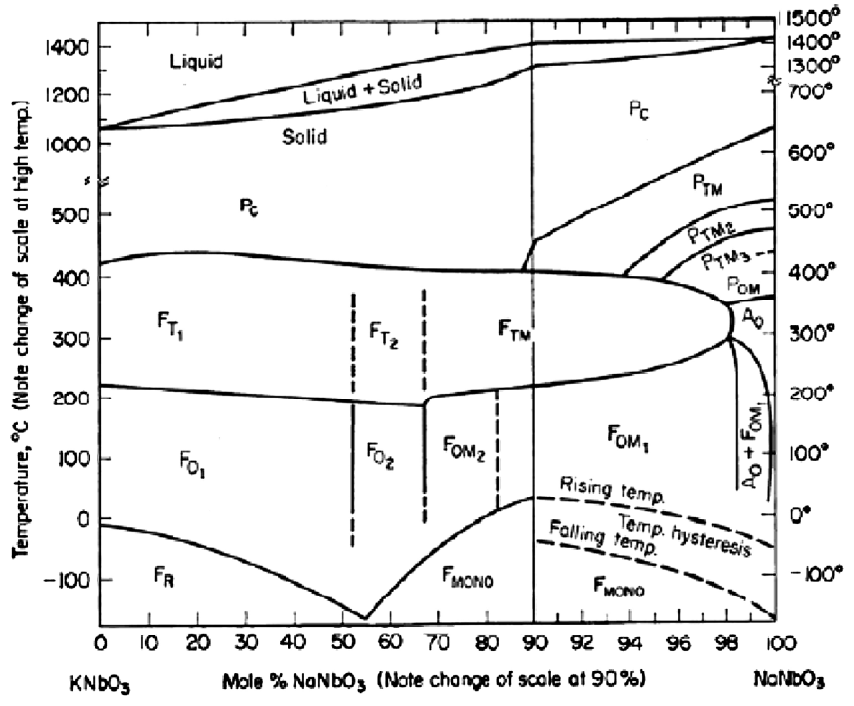

Fig. 4. Phase diagram of $(\mathrm{K}, \mathrm{Na}) \mathrm{NbO}_{3}$ system. ${ }^{[4]}$ This phase diagram is much different from that of $\mathrm{Pb}(\mathrm{Zr}, \mathrm{Ti}) \mathrm{O}_{3}$ of Fig. 1.

온에서는 강유전 특성을 보여주나, 이른바 $100{ }^{\circ} \mathrm{C}$ 주위의 탈분 극 온도(depolarization temperature)와 $300{ }^{\circ} \mathrm{C}$ 정도의 상전이 온도 사이의 상에 대한 명확한 특성이 잘 규명되지 않았으며 특히 반강유전(antiferroelectric) 특성을 보여주기 때문에 실제 로는 BT와 같이 상전이 온도가 충분히 높지 않다는 문제점을 여전히 가지고 있다.

세 번째 후보 물질들은 $\mathrm{B}$-자리를 5 가 원소인 $\mathrm{Nb}$ 이 차지하는 니오비움 산화물이다. 이 경우 $\mathrm{A}$-자리에는 1 가 원소인 $\mathrm{Na}$ 이나 $\mathrm{K}$ 가 차지하게 된다. 그런데 니오비움 산화물의 경우 $\mathrm{NaNbO}_{3}$ 와 $\mathrm{KNbO}_{3}$ 의 강유전 상전이 온도가 크게 차이가 나지 않으며, 그림 4의 상태도에 나타난 바와 같이 $\left(\mathrm{K}_{0.5} \mathrm{Na}_{0.5}\right) \mathrm{NbO}_{3}(\mathrm{KNN})$ 계 의 상전이 현상이 PZT의 경우와 크게 다르다. 일반적으로 상경 계 영역이라고 불리는 조성의 $\mathrm{KNN}$ 의 경우에도 PZT 수준의 좋 은 압전 특성을 보여주지 못하는 것으로 알려져 있다. 이는 PZT의 경우 상경계 영역이 사방정상과 정방정상이 만나는 경우 인데 비하여 $\mathrm{KNN}$ 의 경우에는 그 차이가 별로 크지 않은 같은 사방정상 사이의 경계이기 때문이다. $\mathrm{A}$-자리에 가장 가벼운 $\mathrm{Li}$ 이 차지하는 경우 아주 유명한 강유전체인 니오비움산 리튬 $\left(\mathrm{LiNbO}_{3}\right)$ 이 되는데 이 강유전체의 압전 특성은 응용이 될 정도 로 높지 않는 것으로 보고되었다. 2004년도에는 이런 니오비움 산화물을 바탕으로 최적의 조성과 더불어 반응성 틀을 이용한 알갱이 성장(RTGC, reactive template grain growth) 방법을 활용하여 거의 PZT 수준의 압전 특성을 보여주는 세라믹 재료 의 결과를 보여주었으나 제조 방법의 어려움 등으로 널리 활용

\section{REFERENCES}

[9] Y. Saito et al., Nature 432, 84 (2004). 
되지는 못하였다. ${ }^{[9]}$ 아울러 니오비움 산화물은 제조 공정 중에 공기 중의 수분을 흡수하는 문제 등으로 충분히 높은 밀도의 세라믹 재료를 만들기 어렵다는 문제점도 가지고 있다.

이렇게 현재 비납계 압전 재료의 연구 개발이 전 세계적으로 활발히 이루어지고 있으나 상전이 온도와 압전 계수 값의 크기 등의 문제로 아직 PZT를 완벽하게 대체할 수 있는 물질은 개 발되지 않은 상태이다.[10] 이런 문제의 해결은 다양한 조성의 시도를 통한 우수한 물성의 압전 재료 개발이라는 연구방법에 서 압전 특성은 물질의 어떤 전자구조, 결정구조 등의 기본 원 리에 의하여 결정되는지, 강유전 상전이 온도 및 자발 분극은 어떤 원리에 의하여 결정되는지에 대한 근본적인 질문에 대한 해답을 요구하고 있다. 최근 이런 주제들에 대한 이론적인 계산 시도 및 그 결과들이 보고되고 있으나 응용에 활용될 수 있을 정도의 만족스러운 결과를 얻지 못하고 있다. 그 원인의 하나는 강유전체 및 압전체들이 작은 조성이나 비화학양론의 변화에도 물성이 크게 변하고 재료의 결함도 물성에 큰 영향을 미치는 특성으로 인하여 이론적인 계산이 쉽지 않다는 특성을 가지고 있다. 그런데 이와 관련하여 더 큰 어려움은 아직 이론적인 계 산을 충분히 할 수 있을 정도의 충분한 실험 사실들이 축적되 지 못하였다는 점에 있다. 이런 측면에서 당장의 응용을 위한 개발에 몰두할 뿐만 아니라 기본적인 물성에 대한 이해를 높이 기 위한 실험 결과들을 충분히 축적하는 것이 기본 물성의 이 해나 응용 개발을 위해서도 모두 중요하다고 하겠다.

\section{결 론}

친환경 비납계 압전체에 대한 기본 연구나 응용 개발의 상황 과 관련하여 한 가지 사례를 들면서 이 글을 마치고자 한다. 현재 압전체의 응용 분야로 큰 관심을 받고 있는 예가 이른바 에너지 수확(energy harvesting)이다. 사람들이 많이 다니는 지 하철 역이나 심지어는 디스코 덱에서 사람들의 발걸음과 같은 움직임에서 나오는 진동을 에너지로 얻고자 하는 시도들이 신 문 기사에 등장하곤 한다. 이렇게 일반적으로 버려지는 에너지 를 모아서 유용하게 활용하려는 시도가 에너지 수확 소자이며 압전 재료와 함께 열전 재료가 유용한 후보 물질로서 많이 연
구되고 있다. 그런데 에너지 수확소자에서 얻어지는 에너지의 양 혹은 에너지 밀도가 너무 작거나 낮아서 현재의 발전 시스 템과는 비교가 되지 않을 정도이다. 그러면 왜 압전 재료를 에 너지 수확소자로 개발하여야 하는가?

이러한 문제 제기는 생물 종의 다양성에서 그 해답의 일단을 얻을 수 있다고 생각한다. 지구 위에는 다양한 생물 종이 존재 하지만 최근 지구 환경의 변화 등의 원인으로 인하여 휘귀종의 급속한 멸종으로 지구의 생물 종의 다양성이 큰 위협을 받고 있으며 생물 종의 다양성을 보존하기 위한 전 세계적인 노력이 이루어지고 있다. 이렇게 지구에서 다양한 생물 종이 생겨난 이 유나 또 생물 종의 다양성을 보존해야 하는 이유는 지구에 다 양한 환경이 존재하고 그 환경에 적응하는 과정에서 생물 종이 나타났으며, 다양한 생물 종을 보호함으로써 급격하게 변화하는 지구 환경에서 지구의 생명의 그물을 튼튼하게 이어갈 수 있는 가장 중요한 요소가 생명의 다양성이기 때문이다. 이러한 생물 종의 다양성 논의를 '에너지원의 다양성'으로 바꾸어서 생각해 볼 수 있다. 전기에너지를 중심으로 한 현재의 에너지 환경은 원자력이나 석유, 천연가스, 석탄 등과 같은 화석 연료에 집중 되어 있다. 이러한 문제는 환경오염이나 자원의 고갈이라는 문 제 이외에도 에너지원이 너무 적은 종류에 집중되어 있다는 문 제를 가지고 있다. 에너지를 소비하는 측면에서도 오늘날의 거 의 대부분의 활동이 전기 스위치를 켜는 것으로 시작되는 것으 로 볼 수 있듯이 에너지원이 다양하지 못하다. 이러한 환경의 문제점은 외부의 돌발적인 환경의 변화에 대응하기 어렵다는 점이다. 미국의 대형 허리케인 샌디에 의한 대규모 정전 사태나 일본의 원자력 발전소 사태 등에서 여실히 드러난다. 이런 위험 을 줄이기 위해서도 다양한 에너지원의 필요성은 충분하다. 특 히 다양한 환경에서 그 자체로 에너지를 얻을 수 있는 압전체 를 이용한 에너지 수확소자의 개발이 단순한 에너지 밀도를 바 탕으로 한 주장으로부터 독립적으로 발전할 수 있어야 할 것이 다.

\section{REFERENCES}

[10] T. K. Song, Ceramist (The Korean Ceramic Society) 12, 33 (2009). 